\title{
ZAKAT FOR THE ELDERLY: A Survey of Mustahiks and An Islamic Law Perspective
}

\author{
Rizal Fahlefi', Alimin² \\ ${ }^{1,2}$ State Institute for Islamic Studies (IAIN) Batusangkar, Sumatera Barat, Indonesia \\ Jl. Sudirman No. 137 Kuburajo Limakaum Batusangkar, Sumatera Barat \\ E-mail: 'rizalfahlefi@iainbatusangkar.ac.id, 2alimin@iainbatusangkar.ac.id
}

\begin{abstract}
The study aims to find out a general description of mustahiks of old-age insurance program from National Zakat Agency (BAZNAS) of Tanah Datar Regency and to analyse the legal status of the program from Islamic law perspective. The old-age insurance program is distribution of consumptive zakat permanently throughout life for the elderly. The researcher used a survey method. The results showed that the old-age insurance program is directed to meet the basic needs of elderly mustahiks. The characteristics of the elderly mustahiks are as follows: $90 \%$ are women, $45 \%$ are classified as the old-old, 50\% have never attended school, $60 \%$ are sick, $85 \%$ are non-potential elderly people, $55 \%$ live in unworthy shelter, $65 \%$ live alone, before receiving zakat $80 \%$ meet their needs with the help of others, $80 \%$ have no income other than zakat. These facts support that the consumptive zakat for the elderly must be continued, because it greatly helps elderly welfare. Although there is no specific argument regarding zakat for the elderly, it doesn't contradict the provisions of Islamic law. If the Caliphs Abu Bakr, Umar, and 'Ali decided on a policy of providing compensation for non-Muslim elderly from Baitul Mâl, for Muslim elderly ofcourse even more important.
\end{abstract}

Keywords: consumptive; elderly; old-age insurance; zakat; Islamic law.

\begin{abstract}
Abstrak: Penelitian ini bertujuan untuk mengetahui gambaran umum dari mustahik program jaminan hari tua dari Badan Amil Zakat Nasional (BAZNAS) Kabupaten Tanah Datar dan untuk menganalisis status hukum program perspektif hukum Islam. Program jaminan hari tua merupakan penyaluran zakat konsumtif secara permanen bagi lansia sepanjang hidupnya. Peneliti menggunakan metode survei. Hasil penelitian menunjukkan bahwa program jaminan hari tua bertujuan untuk memenuhi kebutuhan dasar para mustahik lansia. Karakteristik mustahik lansia tersebut adalah sebagai berikut: 90\% diantaranya adalah perempuan, 45\% diklasifikasikan sebagai lansia berumur sangat lanjut, 50\% tidak pernah bersekolah, 60\% dalam kondisi sakit, $85 \%$ merupakan lansia yang tidak potensial, 55\% tinggal di tempat tinggal yang tidak layak, $65 \%$ tinggal sendirian, sebelum menerima zakat $80 \%$ memenuhi kebutuhan mereka dengan mengandalkan bantuan orang lain, $80 \%$ tidak memiliki penghasilan selain zakat. Fakta-fakta ini mendukung bahwa program zakat konsumtif untuk lansia mesti dilanjutkan, karena sangat membantu kesejahteraan lansia. Meskipun tidak ada dalil khusus tentang alokasi zakat untuk lansia, tetapi hal tersebut tidak bertentangan dengan ketentuan hukum Islam. Jika Khalifah Abu Bakr, Umar, dan 'Ali pernah mengambil kebijakan untuk memberikan santunan kepada lansia non-Muslim dari Baitul Mâl, maka menyantuni lansia Muslim tentu lebih utama lagi.
\end{abstract}

Kata kunci: konsumtif; lansia; jaminan hari tua; zakat; hukum Islam.

\section{Introduction}

The distribution of zakat by the National Zakat Agency (Badan Amil Zakat Nasional/ 'BAZNAS') in Indonesia can be classified into two types, namely distribution for consumptive purposes and distribution for productive purposes. Consumptive zakat is zakat which is given directly and is intended for those who are poor. Zakat is directed to meet the basic necessities of life that are primary, such as food, clothing and shelter in a reasonable manner. Another case with consumptive zakat, productive zakat is the distribution of zakat funds for productive business in the context of empowerment, it means that zakat is no longer given to mustahik (zakat beneficiaries) then consumed, but rather zakat will continue to grow and develop. Productive Zakat is given to the poor people who have jobs 
and skils but their incomes are insufficient to meet their daily needs.

Specific research on consumptive zakat is still rarely done. Specific research on consumptive zakat that the author found was only research conducted by Harisah \& Zainulloh, ${ }^{1}$ while other studies on consumptive zakat emphasize the comparison between consumptive zakat and productive zakat. $^{2}$

The attention of many zakat researchers is directed towards productive zakat, because productive zakat is seen as a solution to the problem of poverty that has taken root in the community and as an effort to improve the welfare in order to become a more prosperous community. Productive Zakat has further goals, not just meeting immediate needs but forming mustahik independence so that they no longer belong to the poor.

Various research results have also proven that productive zakat through empowerment programs can improve the welfare of the poor ${ }^{3}$ and reduce the percentage of poor people. ${ }^{4}$ The research

${ }^{1}$ Harisah \& Zainulloh, "Praktik Distribusi Zakat Konsumtif Tradisional di Karang Penang Sampang”, Ulûmuna: Jurnal Studi Keislaman, vol. 5, no. 2 (2019), pp. 130-145.

${ }^{2}$ Haris Al-Amin, "Pengelolaan Zakat Konsumtif dan Zakat Produktif (Suatu Kajian Peningkatan Sektor Ekonomi Mikro dalam Islam)", Jurnal Ekonomi Dan Bisnis (EKONIS), vol. 14, no. 2 (2015), pp. 1-15; Khalifah Muhamad Ali, Nydia Novira Amalia, \& Salahuddin El Ayyubi, "Perbandingan Zakat Produktif dan Zakat Konsumtif dalam Meningkatkan Kesejahteraan Mustahik", Al-Muzara'ah, vol. 4, no. 1 (2016), pp. 19-32.

${ }_{3}^{3}$ Damanhur, Amiur Nuruddin, \& Saparuddin Siregar, "The Model of Productive Zakat Distribution in Increasing The Society Welfare In Aceh Province", IOSR Journal of Humanities and Social Science, vol. 22, no. 11 (2017), pp. 77-82; Hafas Furqani, Ratna Mulyany, \& Fahmi Yunus, "Zakat for Economic Empowerment of The Poor in Indonesia: Models and Implementations", Iqtishadia, vol. 11, no. 2 (2018), pp. 392-411.

4 Martavevi Azwar, "Zakat dan Kesejahteraan Sosial", Islaminomic, vol. 5, no. 2 (2016), pp. 59-74; Nazamul Hoque, Mohammad Aktaruzzaman Khan, \& Kazi Deen Mohammad, "Poverty Alleviation by Zakah in a Transitional Economy: A Small Business Entrepreneurial Framework", Journal of Global Entrepreneurship Research, vol. 5, no. 7 (2015), pp. 1-20; Anthony Mayes, Deny Setiawan, Ulfira Isbah, \& Hilmah Zuryani, "The Role of Productive Zakat for Helping Poor Community in Rokan Hulu Regency (Case Study of National Amil Zakat of Rokan Hulu Regency)", International Journal of Finance and Accounting, vol. 6, no. 6 (2017), pp. 179-185. which is not accessible by bank financial institution. The mentoring process involves planning, implementing, supervising and controlling also evaluating the program, becoming one program of the amil zakat in managing productive zakat, so it is expected to create economic circulation, increase the productivity of community businesses, results also came to the conclusion that if zakat is managed productively such as through economic empowerment, zakat will be able to perform its functions optimally to realize the social welfare. ${ }^{5}$

According to the Islamic law, distribution of zakat for productive purpose or mustahik empowerment is justifiable, as long as the consumptive needs were completed. ${ }^{6}$ Based on this law, it can be understood that the nature of zakat is to fulfill consumptive needs. Distribution of zakat for productive business is permitted if consumptive needs have been met. Although productive zakat has been proven to be able to improve the welfare of the community, especially mustahik, it cannot be denied that there are conditions where mustahik actually requires consumptive zakat rather than productive zakat. This is caused by a variety of conditions, one of which is due to aging.

It is recognized that productive zakat is effective in increasing the welfare of mustahik, but productive zakat can only be given to the mustahik of working age group, whereas for older mustahik productive zakat is not appropriate because they no longer have the ability to participate in empowerment programs (unable to

increase income/yields economically and sustainable. The methodology used in this study is descriptive qualitative method to see the effect of productive zakat on the empowerment of the poor through the poverty index. This research consists of primary data and secondary data. Primary data is obtained from the survey results or distributed questionnaires, and conducted in-depth interviews with productive Zakat program managers in Baznas and Mustahik as participants of community empowerment programs through productive zakat. While secondary data is obtained from BAZNAS Program Report on the internet, some literatures, articles from magazines, journals, newspapers, or internet. This study uses a number of analysis tools, which are: headcount ratio, to find out how many and percentage of poor families; poverty gap ratio and income gap ratio, used to determine depth level of poverty; and the Sen index as well as the Foster, Greer and Thorbecke (FGT

5 Maltuf Fitri, "Pengelolaan Zakat Produktif sebagai Instrumen Peningkatan Kesejahteraan Umat”, Economica: Jurnal Ekonomi Islam, vol. 8, no. 1 (2017), pp. 149-173; Abdurrohman Kasdi, "Filantropi Islam untuk Pemberdayaan Ekonomi Umat (Model Pemberdayaan ZISWAF di BMT se-Kabupaten Demak)", Iqtishadia, vol. 9, no. 2 (2016), pp. 227-245; Nilda Susilawati, Andang Sunarto, \& Rohimin, "Zakat Community Development Program Through A Zakat Village Index Approach", MADANIA, vol. 23, no. 2 (2019), pp. 191-202.

${ }^{6}$ Anwar, "The Law of Productive Zakat in Islam and Its Impact Towards Economy”, International Journal of Engineering Technologies and Management Research, vol. 4, no. 2 (2017), pp. 10-21. 
work). Therefore, the appropriate zakat for elderly mustahiks is consumptive zakat in the form of direct assistance to meet their daily needs, because it is in accordance with their current conditions.

The elderly phase is a phase that cannot be denied. When someone enters the elderly phase, a number of changes occur in his life, such as changes in status, changes in role, and changes in psychological conditions. When someone enters the elderly phase, then a number of declines also occur such as decreased physical abilities, decreased ability to think, and decreased health. These conditions result in reduced social activity of the elderlies and reduced interaction with the environment of them.

The elderly often experience various kinds of problems caused by various factors, including economic factors. Economically, the elderly population is no longer productive because of the reduced ability to work. Because of the reduced ability to work, then the amount of income decreases or even disappears altogether. At that time, the elderly began to depend on others. This condition causes the elderly to be often regarded as a burden rather than as a resource. ${ }^{7}$ Therefore, consumptive zakat for the poor elderly is needed.

During this time, research on the elderly has been done. Research that has been conducted on the elderly is focused on several aspects, including policy aspects related to the welfare of the elderly, ${ }^{8}$ factors that affect the welfare of the elderly, ${ }^{9}$ legal

7 Kementerian Koordinator Bidang Pengembangan Manusia dan Kebudayaan RI, Analisis Kebijakan Pemberdayaan dan Perlindungan Sosial Lanjut Usia, (Jakarta: Deputi Bidang Koordinasi Penanggulangan Kemiskinan dan Perlindunganm, 2015), p. 3.

8 Ivo Rangkoly, Patar Rumapea, \& Salmin Dengo, "Implementasi Kebijakan Bantuan Kesejahteraan Lanjut Usia di Kecamatan Tanimbar Selatan Kabupaten Maluku Tenggara Barat", Jurnal Administrasi Publik, vol. 2, no. 3 (2014), pp. 3950; Mona Silviany, "Implementasi Kebijakan Kesejahteraan Sosial Lanjut Usia di Kecamatan Palu Barat Kota Palu”, E-Jurnal Katalogis, vol. 3, no. 5 (2015), pp. 77-85.

9 Lukmanul Hakim \& Niken Hartati, "Sumber-sumber Kebahagiaan Lansia Ditinjau dari Dalam dan Luar Tempat Tinggal Panti Jompo", Jurnal RAP UNP, vol. 5, no. 1 (2014), pp. 3242; Mulyati, Kenty Martiatuti, \& Rasha, "Pengaruh Dukungan Sosial Keluarga Terhadap Kualitas Hidup dan Kesejahteraan Lansia”, JKKP: Jurnal Kesejahteraan Keluarga Dan Pendidikan, vol. 5, no. 1 (2018), pp. 1-8; AA Raka Riani Tanaya \& I Gusti Wayan Murjana Yasa, "Kesejahteraan Lansia dan Beberapa Faktor yang Mempengaruhi di Desa Dangin Puri Kauh", Piramida, vol. 11, no. 1 (2015), pp. 8-12. protection for the elderly, ${ }^{10}$ working elderly, ${ }^{11}$ elderly services in nursing homes, ${ }^{12}$ empowerment of the elderly, ${ }^{13}$ and integrated health service post (Posyandu) for the elderly. ${ }^{14}$ However, research specifically discussing the zakat program for the welfare of poor elderly has not been found.

Various programs prepared for the elderly are proven to have improved the welfare of the elderly. The research by Kim \& Jin ${ }^{15}$ shows that various welfare services provided to the elderly have a positive effect on the welfare of the elderly. Hakim \& Hartati's research ${ }^{16}$ also shows that prosperity (namely conditions when the basic needs of the elderly can be fulfilled such as food, clothing, shelter, and health) is the most

${ }^{10}$ Marcelia Oktavia Gosal \& Yuwono Prianto, "Perlindungan Hukum Terhadap Lanjut Usia yang Mengalami Kekerasan Psikologis dan Finansial”, Era Hukum, vol. 2, no. 2 (2017), pp. 294314; Marjohan, "Perlindungan Hukum Terhadap Orang Jompo di Panti (Studi Kasus di Panti Jompo Kota Palembang)", Nurani, vol. 18, no. 2 (2018), pp. 77-99.

11 Junaidi, Erfit, Purwaka Hari Prihanto, "Faktor-faktor Sosial Ekonomi yang Mempengaruhi Keterlibatan Penduduk Lanjut Usia dalam Pasar Kerja di Provinsi Jambi”, Masyarakat, Kebudayaan Dan Politik, vol. 30, no. 2 (2017), pp. 197-205; Jati Waskito, "Faktor-faktor Pendorong Keniatan Pekerja Lansia untuk Melanjutkan Bekerja. Benefit", Jurnal Manajemen Dan Bisnis, vol. 18, no. 2 (2014), pp. 70-87; Atik Widiastuti, "Pengaruh Pendidikan, Jam Kerja, dan Pengalaman Kerja Terhadap Pendapatan Tenaga Kerja Lansia”, Jurnal Pendidikan Dan Ekonomi, vol. 7, no. 3 (2018), pp. 253-262.

${ }^{12}$ Lia Shafira Arlianty, Melly Sri Sulastri Rifa'i, \& Yoyoh Jubaedah, "Analisis Relevansi Program dan Pelaksanaan Pelayanan Lansia di Balai Perlindungan Sosial Tresna Werdha Ciparay Bandung", Jurnal FamilyEdu, vol. 1, no. 1 (2015), pp. 8-24.

13 Febriyati \& Suyanto, "Pemberdayaan Lansia Melalui Usaha Ekonomi Produktif oleh Bina Keluarga Lansia (BKL) Mugi Waras di Kabupaten Sleman", Jurnal Pemberdayaan Masyarakat, vol. 1, no. 1 (2017), pp. 207-225; M. D. Pradeep \& Charan Raj, "Recent Trends of Socio-Economic Empowerment of Elderly- Interventions Towards Broad Based Benefits in India”, International Journal of Current Research and Modern Education (IJCRME), vol. 1, no. 1 (2016), pp. 692-700.

${ }_{14}$ Yuli Kusumawati, Yulisna Mutia Sari, \& Siti Zulaekah, "Pengembangan Kegiatan Posyandu Lansia Anthurium di Surakarta”, Warta LPM, vol. 19, no. 2 (2016), pp. 125-133; Mindianata Putri, "Faktor-Faktor yang Berpengaruh Terhadap Niat Keaktifan Lansia dalam Mengikuti Posyandu Lansia”, Jurnal Promkes, vol. 6, no. 2 (2018), pp. 213-225; Pomarida Simbolon \& Nagoklan Simbolon, "Association between Social-Cultural and the Utilization of Elderly Integrated Health Services (Posyandu Lansia) in Hamparan Perak Health Center", Unnes Journal of Public Health, vol. 7, no. 1 (2018), pp. 50-54.

${ }^{15}$ Danya Kim \& Jangik Jin, "The Impact of Welfare Facilities on Happiness of the Elderly: Evidence from Seoul, Korea", Journal of Planning Education and Research, vol. January (2019), pp. 1-14.

${ }^{16}$ Lukmanul Hakim \& Niken Hartati, "Sumber-sumber Kebahagiaan Lansia Ditinjau dari Dalam dan Luar Tempat Tinggal Panti Jompo", Jurnal RAP UNP, vol. 5, no. 1 (2014), pp. 32-42. 
influential factor in elderly happiness. Fanany \& Fanany ${ }^{17}$ also explained that as a manifestation of the role of religious institutions, the National Zakat Agency of West Sumatra Province had conducted a program to support the welfare of the elderly, in the form of distributing zakat in the form of food and money to the poor elderlies to meet the needs of them.

BAZNAS of Tanah Datar Regency in the Province of West Sumatra, Indonesia, also has a special program for elderly mustahik. The program can be said as the old-age insurance, because zakat is given continuously throughout the life of the elderly mustahik. As an authorized institution in the management of zakat in Tanah Datar Regency, BAZNAS Tanah Datar distributes zakat for the elderly mustahik every month, accompanied directly by BAZNAS officers. The giving of zakat aims to meet consumer needs, namely meeting the basic needs of the elderly.

The development of social welfare is an embodiment of efforts to achieve the nation's goals mandated in the 1945 Constitution of the Republic of Indonesia (Undang-Undang Dasar Negara Republik Indonesia Tahun 1945). The fifth pinciple of Pancasila states that social justice is for all Indonesian people. In addition, the purpose of the state mandated in the Preamble of the 1945 Constitution of the Republic of Indonesia in the fourth paragraph is "Protect all Indonesians and all Indonesian spilled blood, promote public welfare, improve the life of the nation, and participate in carrying out world order, based on independence, eternal peace, and social justice".

According to Law No. 13 of 1998 concerning Elderly Welfare, ${ }^{18}$ the elderly are people who have aged 60 years and over. Kholifah ${ }^{19}$ explains that when entering old age, a person will experience physical setbacks, mental setbacks, and social setbacks little by little until he cannot carry out his daily duties. So for many people, old age is an unpleasant time.

${ }^{17}$ Rebecca Fanany \& Ismet Fanany, The Elderly Must Endure: Ageing in the Minangkabau Community in Modern Indonesia (Singapura: ISEAS-Yusof Ishak Institute, 2019), p. 88.

${ }^{18}$ See Law No. 13 of 1998 concerning Elderly Welfare

19 Siti Nur Kholifah, Keperawatan Gerontik (Jakarta: Kementerian Kesehatan RI, 2016), p. 5.
According to the provisions of Law No. 13 of 1998 concerning Elderly Welfare the elderly are divided into two groups, namely potential elderly and non-potential elderly. Potential elderly are the elderly who can still be productive economically and socially, while the non-potential elderly are the elderly who are already helpless. Providing services to the elderly is also divided into two forms of service, namely services for potential elderly in the form of social assistance, while for non-potential elderly in the form of social protection. Social protection implies the service to the elderly as a whole, because the elderly are no longer able to carry out any economic activity.

Article 1 of Law No. 13 of 1998 also explains that social welfare is a condition of meeting the material needs, spiritual needs, and social needs of citizens, so that they can live properly and be able to develop themselves, so they can carry out their social functions. Based on this article, the government is required to provide social protection, namely ease of service for nonpotential elderly in order to improve their level of social welfare.

Republic of Indonesia Government Regulation No. 43 of 2004 concerning Implementation of Efforts to Improve Social Welfare Elderly ${ }^{20}$ Article 1 explains that efforts to improve social welfare of the elderly are a series of activities carried out in a coordinated manner between the government and the community to empower the elderly so that the elderly can continue to carry out their social functions and play an active role naturally in living in a society and in a nation.

Efforts to improve social welfare for the elderly that have been implemented by the Government include social protection, social assistance, maintenance of social welfare, and empowerment. ${ }^{21}$ The government's concern for the elderly is also shown by the determination of the elderly's day. The government has set May 29 as elderly day. In addition, the government has also formed the National Commission for the Elderly

\footnotetext{
20 Undang-Undang Nomor 13 Tahun 1998 tentang Kesejahteraan Lanjut Usia [Law No.13 of 1998 on Elderly Wefare]

${ }^{21}$ Misnaniarti, "Analisis Situasi Penduduk Lanjut Usia dan Upaya Peningkatan Kesejahteraan Sosial di Indonesia”, Jurnal Ilmu Kesehatan Masyarakat, vol. 8, no. 2 (2017), pp. 67-73.
} 
(National Commission for the Protection of Older Citizens) based on Presidential Decree Number 52 of 2004 concerning the Establishment of the National Commission for Elderly (Keppres Nomor 52 Tahun 2004 tentang Pembentukan Komisi Nasional Lanjut Usia). The National Commission for the Elderly is the coordinator of efforts to improve the welfare of the elderly in Indonesia. Law Number 36 of 2009 concerning Health ${ }^{22}$ also states that the government is obliged to guarantee the availability of health service facilities and facilitate the elderly to be able to live independently and productively.

As the elderly get older, the physiological function of the elderly decreases due to the aging process, so that many non-communicable diseases emerge. In addition, degenerative problems reduce the body's resistance so it is susceptible to infectious diseases. Non-communicable diseases in the elderly include hypertension, stroke, diabetes mellitus, and arthritis or rheumatism. The infectious diseases that mostly affect the elderly are tuberculosis, diarrhea, pneumonia, and hepatitiss. ${ }^{23}$

In 2019, the percentage of elderly people in Indonesia is 9.60 percent or around 25.64 million people. The percentage of elderly people in Indonesia is dominated by young elderly (aged 60-69 years) whose percentage is 63.82 percent, the rest are middle aged people (aged $70-79$ years) that is 27.68 percent and old elderly (aged $80+$ years) namely 8.50 percent..$^{24}$ Most of the elderly $(61.7 \%)$ still play the role of head of the household. This role is considered as the most severe role because the elderly are responsible for meeting the daily needs of the household. ${ }^{25}$

Economically, the position of the elderly in Indonesia can be divided into three groups. First is the elderly who are well-established, namely the elderly who are highly educated, have good

22 Undang-Undang Nomor 36 tahun 2009 tentang Kesehatan [Law No.36 of 2009 on Health]

${ }^{23}$ Kementerian Kesehatan RI, "Gambaran Kesehatan Lanjut Usia di Indonesia", Buletin Jendela Data Dan Informasi Kesehatan, Kementerian Kesehatan RI, 1, (2013), pp. 1-18.

${ }^{24}$ Badan Pusat Statitstik, Statistik Penduduk Lanjut Usia 2019 (Jakarta: Badan Pusat Statistik, 2019), p. vii.

${ }^{25}$ Misnaniarti, "Analisis Situasi Penduduk Lanjut Usia dan Upaya Peningkatan Kesejahteraan Sosial di Indonesia", Jurnal Ilmu Kesehatan Masyarakat, vol. 8, no. 2 (2017), pp. 67-73. productive end years, and still have income for example from pensions. Elderly who have the ability to invest and are willing to take insurance will be established in old age. Second is the elderly who are less established, that is the elderly who are economically sufficient, but the elderly are still lacking for health needs and self-actualization. Third is the elderly who are vulnerable, namely the elderly who do not have economic capacity, the elderly are dependent on others, and the elderly are unable to maintain their health standards independently. ${ }^{26}$

The largest financial source of around 79.91\% of elderly households in Indonesia is from working household members. The elderly get help from children or families. The assistance is in the form of money or other needs such as food, clothing, and health. ${ }^{27}$ For economically weak people, supporting their elderly family members is very burdensome for their finances. This condition forces the elderly to keep working as long as they can. ${ }^{28}$ In fact, people who are elderly are generally no longer able to work in jobs that require physical labor, so if the elderly work, the resulting productivity is less, as a result the wages earned by the elderly are also less. Statistical data shows that $50 \%$ of the working elderly population is low income. This makes the elderly vulnerable to living in poverty. ${ }^{29}$

Islam strongly advocates respecting the elderly and caring for them. Many theorems of the Quran and the Hadith ordered Muslims to do good to the elderly. The scholars also expressed the importance of respecting elderly people. ${ }^{30}$ Zakat is a form of realization of social insurance, ${ }^{31}$

${ }^{26}$ Kementerian Koordinator Bidang Pembangunan Manusia dan Kebudayaan RI, Analisis Kebijakan Pemberdayaan dan Perlindungan Sosial Lanjut Usia, (Jakarta: Deputi Bidang Koordinasi Penanggulangan Kemiskinan dan Perlindungan, 2015), p. 18

${ }_{27}$ Badan Pusat Statitstik, Statistik Penduduk Lanjut Usia 2019, (Jakarta: Badan Pusat Statistik, 2019), p. 79.

${ }_{28}$ Rebecca Fanany \& Ismet Fanany, The Elderly Must Endure: Ageing in the Minangkabau Community in Modern Indonesia, (Singapura: ISEAS-Yusof Ishak Institute, 2019), p. 88.

29 Badan Pusat Statitstik, Statistik Penduduk Lanjut Usia 2019, (Jakarta: Badan Pusat Statistik, 2019), p. 79.

30 Benaouda Bensaid \& Fadila Grine, "Old age and Elderly Care: An Islamic Perspective", Cultura. International Journal of Philosophy of Culture and Axiology, vol. 11, no. 1 (2014), pp. 141-163.

${ }^{31}$ Naerul Edwin Kiky Aprianto, "Kontruksi Sistem Jaminan 
therefore one of the commands in Islam related to efforts to pay attention to the elderly is zakat, especially consumptive zakat. According to Harisah \& Zainulloh, ${ }^{32}$ meeting the needs of those who are poorly consumptive is for those who are physically weak, such as the elderly. Furthermore, it was explained that the poor who receive consumptive zakat are those who are categorized in three terms of quantitative calculations, including: food, clothing and shelter. The original food is full, the original clothing is covered and the original board is for shelter. In another sense, at a certain time, those needs cannot be overcome except by consuming the zakat.

Al-Amin ${ }^{33}$ also explained that consumptive zakat is zakat which is directly intended for those who are unable and in dire need, especially for the poor. Zakat is directed primarily to meet basic needs naturally, and fulfillment of these basic needs is needed by the elderly (one of them) who can't do anything to make a living for their survival. Their needs indeed can only be overcome by consuming zakat in a consumptive manner, for example to meet the needs of food and drink for a certain period of time, to fulfill clothing needs, to meet shelter needs, and to fulfill other urgent needs of life.

\section{Method}

The researcher used a survey method. The research was conducted at the National Zakat Agency of Tanah Datar Regency (BAZNAS Tanah Datar) in the province of West Sumatra in the second semester of 2019. The research sample consisted of twenty beneficiaries of old-age insurance program through the receiving of consumptive zakat permanently from BAZNAS Tanah Datar. Research data were collected through questionnaires and personnal interviews. The data of the questionnaire were analyzed by quantitative

Sosial dalam Perspektif Ekonomi Islam", Economica: Jurnal Ekonomi Islam, vol. 8, no. 2 (2017), p. 252.

${ }^{32}$ Harisah \& Zainulloh, "Praktik Distribusi Zakat Konsumtif Tradisional di Karang Penang Sampang”, Ulûmuna: Jurnal Studi Keislaman, vol. 5, no. 2 (2019), p. 135.

${ }^{33}$ Haris Al-Amin, "Pengelolaan Zakat Konsumtif dan Zakat Produktif (Suatu Kajian Peningkatan Sektor Ekonomi Mikro dalam Islam)", Jurnal Ekonomi Dan Bisnis (EKONIS), vol. 14, no. 2 (2015), p. 4. descriptive analysis technique, and the data of the interview were analyzed by qualitative descriptive analysis technique.

\section{Results and Discussion \\ The Characteristics of the Elderly Mustahiks of Old-age Insurance Program}

One of the zakat distribution programs at National Zakat Agency of Tanah Datar Regency (BAZNAS Tanah Datar) is a permanent consumptive zakat program. Permanent consumptive zakat program is a program of distributing zakat to mustahik permanently. One of the targets of permanent consumptive zakat is the elderly who live in the Tanah Datar Regency. However, certainly not all the elderly are given permanent consumptive charity, permanent consumptive charity is given to the elderly who are classified as mustahik or meet the criteria as mustahik.

The consumptive zakat distribution program for the elderly is carried out in the form of an oldage insurance program, namely the consumptive zakat given to the elderly mustahik throughout life. Based on interviews with elderly mustahiks, it is known that the zakat funds received are used to fulfill basic needs not only for food, clothing, and shelter but also for healthcare. With the receipt of this zakat fund, the life of the elderly becomes calmer and better.

This study investigates twenty elderly mustahiks who have received consumptive zakat permanently through old-age insurance program from the BAZNAS Tanah Datar. The characteristics of them are as follows.

Table 1. The Distribution of Elderly Mustahiks by Sex

\begin{tabular}{cccc}
\hline No & Sex & Frequency & Percentage \\
\hline 1 & Male & 2 & $10 \%$ \\
2 & Female & 18 & $90 \%$ \\
\hline
\end{tabular}

Based on the table 1, it is known that $90 \%$ of the elderly who receive zakat are women, while men are only $10 \%$. This means that women are vulnerable to poverty in their old age. This is due to the fact that in the past most women are housewives who depend entirely on their husbands to fulfill their needs. Therefore, when a woman is 
left dead by her partner, women no longer have the financial resources to meet their needs so that most women live in poverty in their old age. This is the role of permanent consumptive charity for the elderly, especially elderly women. Permanent consumptive charity is given throughout life until the end of his life.

Table 2. The Distribution of Elderly Mustahiks by Age

\begin{tabular}{cccc}
\hline No & Age & Frequency & Percentage \\
\hline 1 & $\begin{array}{c}\text { Ages 60-69 } \\
\text { (Young-old) }\end{array}$ & 4 & $20 \%$ \\
2 & $\begin{array}{c}\text { Ages 70-79 } \\
\text { (Middle-old) }\end{array}$ & 7 & $35 \%$ \\
3 & $\begin{array}{c}\text { Over age } 80 \\
\text { (Old-old) }\end{array}$ & 9 & $45 \%$ \\
\hline
\end{tabular}

The table 2 explains that $45 \%$ of elderly recipients of zakat are old-old age group, 35\% are middle-old age group, and $20 \%$ are young-old age group. This shows that the elderly who are over age 80 no longer have the ability to work, so that they are completely dependent on their family members or the community around them. The young-old age group and middle-old age group still have the ability to work even though not as productive as before. Many of the elderly are still working until the time when they are no longer able to work when the elderly enter the old-old phase. Zakat for the elderly especially for old-old age group is certainly very useful because at that time they are no longer able to work to meet their daily needs.

Table 3. The Distribution of Elderly Mustahiks by Education

\begin{tabular}{cccc}
\hline No & Education & Frequency & Percentage \\
\hline 1 & Educated & 10 & $50 \%$ \\
2 & Uneducated & 10 & $50 \%$ \\
\hline
\end{tabular}

In the aspect of education, the table 3 explains that only $50 \%$ of the elderly have attended school and in general only up to primary school, while $50 \%$ of the elderly have never attended school. Their low education has an impact on their work where they can only work in low-income sectors, so they are unable to save or invest for old age. For this reason, elderly with low education live in poverty. Giving zakat to the elderly will help them to continue their lives because they do not have old age savings and investment.

Table 4. The Distribution of Elderly Mustahiks by Health Condition

\begin{tabular}{cccc}
\hline No & Health Condition & Frequency & Percentage \\
\hline 1 & Healthy & 8 & $40 \%$ \\
2 & Unhealthy & 12 & $60 \%$ \\
\hline
\end{tabular}

The data of the table 4 explain that $60 \%$ of elderly recipients of zakat are unhealthy and only $40 \%$ are healthy. The age factor is a major factor in the health problems of the elderly. The unhealthy condition of the elderly certainly does not allow them to work even though they are still in the age of young-old or middle-old. When the elderly are in an unhealthy condition, the elderly not only need money to fulfill their daily needs, but also they need money to healthcare. Therefore, zakat for the elderly will be able to help them to healthcare as well as to meet their daily needs.

Table 5. The Distribution of Elderly Mustahiks by Potency

\begin{tabular}{cccc}
\hline No & Potency & Frequency & Percentage \\
\hline 1 & Potential & 3 & $15 \%$ \\
2 & Non-potential & 17 & $85 \%$ \\
\hline
\end{tabular}

Based on the table 5 , it can be seen that only $15 \%$ of elderly people are classified as potential elderly, while $85 \%$ among them are no longer potential. Various factors such as age and health factors make the elderly no longer potential. Giving comsumptive zakat especially for elderly people who are no longer potential is certainly very appropriate, because it is impossible for them to be given productive zakat while they cannot be empowered anymore.

Table 6. The Distribution of Elderly Mustahiks by Living Arrangement

\begin{tabular}{cccc}
\hline No & Living Arrangement & Frequency & Percentage \\
\hline 1 & Living with Family & 3 & $15 \%$ \\
& Members & & \\
2 & Living Alone & 17 & $85 \%$ \\
\hline
\end{tabular}


The table 6 explains that $65 \%$ of the elderly live alone not with their families or relatives. This condition worsens the welfare of the elderly. If the elderly live with their family or relatives, of course the fulfillment of their daily needs is more secure, although not sufficient. As for the elderly who live alone, of course experience worse conditions. Zakat given by BAZNAS is certainly very helpful especially for the elderly who live alone, not with their families or relatives.

Table 7. The Distribution of Elderly Mustahiks by Source of Income

\begin{tabular}{cccc}
\hline No & $\begin{array}{c}\text { Source of Income } \\
\text { (before Receiving } \\
\text { Zakat) }\end{array}$ & Frequency & Percentage \\
\hline 1 & Earnings & 4 & $20 \%$ \\
2 & Other Assistance & 16 & $80 \%$ \\
\hline
\end{tabular}

Before receiving zakat, $80 \%$ of elderly people fulfill their daily needs by other assistance, both from family members and from the surrounding community. Only $20 \%$ of them meet their needs with their own income. From this fact, it can be seen that the elderly are vulnerable to not being able to fulfill their basic needs. Therefore, zakat assistance is the right solution to guarantee the life of the elderly.

Table 8. The Distribution of Elderly Mustahiks by Length of Receiving Zakat

\begin{tabular}{cccc}
\hline No & $\begin{array}{c}\text { Length of } \\
\text { Receiving Zakat }\end{array}$ & Frequency & Percentage \\
\hline 1 & $1-2$ years & 5 & $25 \%$ \\
2 & $3-4$ years & 8 & $40 \%$ \\
3 & Over 5 years & 7 & $35 \%$ \\
\hline
\end{tabular}

The elderly have received zakat for several years. The length of time for receiving zakat varies, some have received zakat for more than 5 years (35\%), some have received zakat for 3-4 years (40\%), and some have only received zakat for 1-2 years ( $25 \%$ ). This is related to the ability of BAZNAS in allocating zakat funds for the elderly. Every year, the officers of BAZNAS re-record the elderly data. For example there are elderly people who have died, then the recruitment of new elderly mustahik is carried out.
Based on the research data above, it can be seen that the elderly beneficiaries of the consumptive zakat is classified as the elderly who really need help to meet their basic needs. According to Badan Pusat Statistik ${ }^{34}$, the largest financial source of around $79.91 \%$ of elderly households in Indonesia is from working household members. This data is the same as the findings of this research that $80 \%$ of elderly people fulfill their daily needs before receiving zakat by other assistance, both from family members and from the surrounding community.

\section{Islamic Law Perspective of Zakat for the Elderly}

From a legal aspect, there is no specific argument (dalil) in Islamic law regarding zakat for the elderly and likewise there are no elderly people in the list of eight beneficiaries of zakat, because the most important thing is seen from the side of their need for zakat funds, such as the needy and the poor as the main category. However, Islam's concern for displaced people is unquestionable. So, not helping poor elderly people is very unfair, as stated by Umar ibn alKhatthâb, "not giving compensation to them is unfair (ma anshafnahu), because we have taken advantage of their youth, then we waste them when they are already old" 35 .

If the elderly are categorized as needy or poor, they are included in the priority scale of zakat allocation from the viewpoint of fiqh awlawiyât (priority figh) for two reasons, a) in the elderly, there are many weak sides, namely old condition while old condition itself is a type of disease, and the classification of the elderly as needy or poor, b) if the Caliph Abu Bakr against the inhabitants of Hirah ${ }^{36}$, Umar in Syria37, and 'Ali ibn Abi Thalib38 decided on a policy of providing compensation for the elderly including the expert of dzimmah from

\footnotetext{
${ }^{34}$ Badan Pusat Statitstik, Statistik Penduduk Lanjut Usia 2019, (Jakarta: Badan Pusat Statistik, 2019), p.

35 Abu Yusuf, Al-Kharaj, tahkik Thâha Abd Ra'uf Sa'ad \& Sa'ad Hasan Muhammad, (Kairo: al-Maktabah al-Azhariyah li at-Turâts, t.th.), p. 136.

${ }^{36}$ Abu Yusuf, Al-Kharaj ..., p. 306.

37 Abu Yusuf, Al-Kharaj ..., p. 136.

${ }^{38}$ Nu'aimah Syuman, Al-Islam Baina Keynes wa Marx wa Huquq al-Insan fi al-Islam, (Damaskus: Ittihad al-Kuttab al-'Arab, 2000), p. 73.
} 
baitul mâl and freed them from jizyah, then for the elderly from the Muslim of course even more important. In terms of whether the source of funds to give compensation to non-Muslim elderly comes from the kharaj tax, trade tax, or zakat, there is no argument that explains this problem. The hadith texts only explain that the state is obliged to give compensation to the elderly from the baitul mâl. The source of funds of the baitul mâl is not only from zakat, but also from various sources such as jizyah, kharaj, 'usyr, and ghanimah.

When talking about social justice in Islam, al-Zuhaili ${ }^{39}$ emphasized that basically, under any circumstances, fuqaha obliged the state to ensure the need for food (kafaf) until the need is within a reasonable limit (kifayah) for every citizen within the framework of daf' adh-dharar (the principle of avoiding harm). In this case, the explainer of Kitab al-Minhaj (asy-Syarbaini) to Kitab al-Minhaj (an-Nawawî) questioned, "Is the state's obligation to guarantee only to the limit of emergency or to the limit of perfect sufficiency (tamam al-kifayah)? He replied, "There are two opinions in this matter, the weak opinion states that the state's obligation to guarantee up to the emergency limit, while the strong opinion states that the state's obligation to guarantee up to the kifayah limit." Then al-Zuhailît emphasized more broadly that this obligation covers all citizens, both Muslim and non-Muslim, as stated by fuqaha with the argument of Caliph Umar ibn al-Khatthab who freed jizyah from the elderly from non-Muslim citizens, and provided them with compensation from the baitul mâl by stating that not giving compensation to them is an unfair policy.

The old-age insurance program of BAZNAS Tanah Datar is a manifestation of the role of religious institutions in supporting the welfare of the elderly as mentioned by Fanany \& Fanany ${ }^{41}$ regarding the manifestation of religious institutions in community. In this case, BAZNAS as a religious institution in the economic field certainly has an important role in supporting the welfare of

39 Wahbah Al-Zuhailî, Al-Fiqh al-Islâmi wa Adillatuhu (Beirut: Dâr al-Fikri, 2009), cet. 12, jilid. 8, p. 6394.

${ }^{40}$ Wahbah Al-Zuhailî, Al-Fiqh ..., p. 6395.

${ }^{41}$ Rebecca Fanany \& Ismet Fanany, The Elderly Must Endure: Ageing in the Minangkabau Community in Modern Indonesia, (Singapura: ISEAS-Yusof Ishak Institute, 2019), p. 87.
Muslims through the distribution of zakat for those entitled to receive it.

It is expected that the giving of the zakat can improve the welfare of the elderly. This is in accordance with the results of Tanaya and Yasa's research ${ }^{42}$ which shows that economic factors affect the welfare of the elderly. It means that the higher the economic level of the elderly, the higher the level of welfare. The research results of Mulyati, Rasha, \& Martiatuti43 also showed that instrumental support (eg. material assistance) had a positive effect on the quality of life of the elderly. In addition, the quality of life has a positive relationship with the welfare of the elderly. It means that the more instrumental support the better the quality of life of the elderly and the more the quality of life the better the welfare of the elderly. It is also expected that the giving of the zakat can increase the happiness of elderly lives. This is in accordance with the research of Hakim \& Hartati ${ }^{44}$ that shows that prosperity (namely conditions when the basic needs of the elderly can be fulfilled such as food, clothing, shelter, and health) is the most influential factor in elderly happiness.

\section{Conclusion}

The distribution of zakat for the elderly is in the form of consumptive zakat that is given permanently as a form of the old-age insurance for the elderly mustahiks. The elderly who receive the consumptive zakat are elderly who are classified as mustahiks or meet the criteria as mustahiks. Based on the characteristics of the elderly who receive the consumptive zakat, it can be concluded that the majority of the elderly are unable to meet their basic needs due to various factors. Although the elderly have family members or close relatives, they cannot help because they also live in poverty. Therefore, the consumptive zakat given by the

${ }^{42}$ AA Raka Riani Tanaya \& I Gusti Wayan Murjana Yasa, "Kesejahteraan Lansia dan Beberapa Faktor yang Mempengaruhi di Desa Dangin Puri Kauh", Piramida, vol. 11 no. 1 (2015), pp. 11-12.

${ }^{43}$ Mulyati, Kenty Martiatuti, \& Rasha, "Pengaruh Dukungan Sosial Keluarga Terhadap Kualitas Hidup dan Kesejahteraan Lansia", JKKP: Jurnal Kesejahteraan Keluarga Dan Pendidikan, vol. 5, no. 1 (2018), pp. 6-7.

${ }_{44}$ Lukmanul Hakim \& Niken Hartati, "Sumber-sumber Kebahagiaan Lansia Ditinjau dari Dalam dan Luar Tempat Tinggal Panti Jompo", Jurnal RAP UNP, vol. 5, no. 1 (2014), p. 35. 
BAZNAS Tanah Datar to the elderly can be said to be very precise, moreover the consumptive zakat are given continuously throughout the life of the elderly, so as to guarantee the fulfillment of the basic needs of the elderly of not just food, clothing, and shelter, but also healthcare. The allocation of zakat for the elderly carried out by BAZNAS Tanah datar doesn't contradict the provisions of Islamic law.

\section{References}

Al-Amin, Haris, "Pengelolaan Zakat Konsumtif dan Zakat Produktif (Suatu Kajian Peningkatan Sektor Ekonomi Mikro dalam Islam)", Jurnal Ekonomi Dan Bisnis (EKONIS), vol. 14, no. 2, 2015.

Ali, Khalifah Muhammad dkk., "Perbandingan Zakat Produktif dan Zakat Konsumtif dalam Meningkatkan Kesejahteraan Mustahik", AlMuzara'ah, vol. 4, no. 1, 2016. https://doi. org/10.29244/jam.4.1.19-32

Anwar, "The Law of Productive Zakat in Islam and Its Impact Towards Economy", International Journal of Engineering Technologies and Management Research, vol. 4, no. 2, 2017. https://doi.org/10.5281/zenodo.293800

Aprianto, Naerul Edwin Kiky, "Kontruksi Sistem Jaminan Sosial dalam Perspektif Ekonomi Islam", Economica: Jurnal Ekonomi Islam, Vol. 8, No. 2, 2017. https://doi.org/10.21580/ economica.2017.8.2.134

Arlianty, Lia Shafira dkk., "Analisis Relevansi Program dan Pelaksanaan Pelayanan Lansia di Balai Perlindungan Sosial Tresna Werdha Ciparay Bandung", Jurnal FamilyEdu, vol. 1, no. 1, 2015.

Azwar, Martavevi, "Zakat dan Kesejahteraan Sosial”. Islaminomic, vol. 5, no. 2, 2016. https://doi.org/10.1145/3132847.3132886

Badan Pusat Statitstik, Statistik Penduduk Lanjut Usia 2019, Jakarta: Badan Pusat Statistik, 2019.

Bensaid, Benaouda \& Fadila Grine, "Old age and Elderly Care: An Islamic Perspective”, Cultura. International Journal of Philosophy of Culture and Axiology, vol. 11, no. 1, 2014. https://doi. org/10.5840/cultura20141119

Damanhur dkk., "The Model of Productive Zakat
Distribution in Increasing The Society Welfare In Aceh Province", IOSR Journal of Humanities and Social Science, vol. 22, no. 11, 2017. https:// doi.org/10.9790/0837-2211067782

Fanany, Rebecca \& Ismet Fanany, The Elderly Must Endure: Ageing in the Minangkabau Community in Modern Indonesia, Singapura: ISEAS-Yusof Ishak Institute, 2019.

Febriyati \& Suyanto, "Pemberdayaan Lansia Melalui Usaha Ekonomi Produktif oleh Bina Keluarga Lansia (BKL) Mugi Waras di Kabupaten Sleman", Jurnal Pemberdayaan Masyarakat, vol. 1, no. 1, 2017.

Fitri, Maltuf, “Pengelolaan Zakat Produktif sebagai Instrumen Peningkatan Kesejahteraan Umat", Economica: Jurnal Ekonomi Islam, vol. 8, no. 1, 2017. https://doi.org/10.21580/ economica.2017.8.1.1830

Furqani, Hafas dkk., "Zakat for Economic Empowerment of The Poor in Indonesia: Models and Implementations", Iqtishadia, vol. 11, no. 2, 2018. https://doi.org/10.21043/ iqtishadia.v11i2.3973

Gosal, Marcelia Oktavia \& Yuwono Prianto, "Perlindungan Hukum Terhadap Lanjut Usia yang Mengalami Kekerasan Psikologis dan Finansial", Era Hukum, vol. 2, no. 2, 2017.

Hakim, Lukmanul \& Niken Hartati, "Sumbersumber Kebahagiaan Lansia Ditinjau dari Dalam dan Luar Tempat Tinggal Panti Jompo", Jurnal RAP UNP, vol. 5, no. 1, 2014.

Harisah \& Zainulloh, "Praktik Distribusi Zakat Konsumtif Tradisional di Karang Penang Sampang", Ulûmuna: Jurnal Studi Keislaman, vol. 5, no. 2, 2019.

Hoque, Nazamul dkk., "Poverty Alleviation by Zakah in a Transitional Economy: A Small Business Entrepreneurial Framework", Journal of Global Entrepreneurship Research, Vol. 5, No. 7, 2015. https://doi.org/10.1186/ s40497-015-0025-8

Junaidi dkk., "Faktor-faktor Sosial Ekonomi yang Mempengaruhi Keterlibatan Penduduk Lanjut Usia dalam Pasar Kerja di Provinsi Jambi", Masyarakat, Kebudayaan Dan Politik, vol. 30, no. 2, 2017. https://doi.org/10.20473/mkp. v30i22017.197-205 
Kasdi, Abdurrohman, "Filantropi Islam untuk Pemberdayaan Ekonomi Umat (Model Pemberdayaan ZISWAF di BMT se-Kabupaten Demak)", Iqtishadia, vol. 9, no. 2, 2016. https://doi.org/10.21043/iqtishadia.v9i2.1729

Kementerian Kesehatan RI, "Gambaran Kesehatan Lanjut Usia di Indonesia”, Buletin Jendela Data Dan Informasi Kesehatan, Kementerian Kesehatan RI, 1, 2013.

Kementerian Koordinator Bidang Pembangunan Manusia dan Kebudayaan RI, Analisis Kebijakan Pemberdayaan dan Perlindungan Sosial Lanjut Usia, Jakarta: Deputi Bidang Koordinasi Penanggulangan Kemiskinan dan Perlindungan, 2015.

Keppres Nomor 52 Tahun 2004 tentang Pembentukan Komisi Nasional Lanjut Usia [Presidential Decree Number 52 of 2004 concerning the Establishment of the National Commission for Elderly].

Kholifah, Siti Nur, Keperawatan Gerontik, Jakarta: Kementerian Kesehatan RI, 2016.

Kim, Danya Kim \& Jangik Jin, “The Impact of Welfare Facilities on Happiness of the Elderly: Evidence from Seoul, Korea", Journal of Planning Education and Research, vol. January, 2019.

Kusumawati, Yuli dkk., "Pengembangan Kegiatan Posyandu Lansia Anthurium di Surakarta", Warta LPM, vol. 19, no. 2, 2016. https://doi. org/10.23917/warta.v19i2.2738

Marjohan, "Perlindungan Hukum Terhadap Orang Jompo di Panti (Studi Kasus di Panti Jompo Kota Palembang)", Nurani, vol. 18, no. 2, 2018.

Mayes, Anthony dkk., "The Role of Productive Zakat for Helping Poor Community in Rokan Hulu Regency (Case Study of National Amil Zakat of Rokan Hulu Regency)", International Journal of Finance and Accounting, vol. 6, no. 6, 2017. https://doi.org/10.5923/j. ijfa.20170606.04

Misnaniarti, "Analisis Situasi Penduduk Lanjut Usia dan Upaya Peningkatan Kesejahteraan Sosial di Indonesia", Jurnal Ilmu Kesehatan Masyarakat, vol. 8, no. 2, 2017. https://doi. org/10.26553/jikm.2017.8.2.67-73

Mulyati, dkk., "Pengaruh Dukungan Sosial Keluarga Terhadap Kualitas Hidup dan Kesejahteraan
Lansia", JKKP: Jurnal Kesejahteraan Keluarga Dan Pendidikan, vol. 5, no. 1, 2018. https:// doi.org/10.21009/jkkp.051.01

Pradeep, M. D. \& Charan Raj, "Recent Trends of Socio-Economic Empowerment of ElderlyInterventions Towards Broad Based Benefits in India", International Journal of Current Research and Modern Education (IJCRME), vol. 1, no. 1, 2016.

Putri, Mindianata, “Faktor-Faktor yang Berpengaruh Terhadap Niat Keaktifan Lansia dalam Mengikuti Posyandu Lansia”, Jurnal Promkes, vol. 6, no. 2, 2018.

Rangkoly, Ivo dkk., "Implementasi Kebijakan Bantuan Kesejahteraan Lanjut Usia di Kecamatan Tanimbar Selatan Kabupaten Maluku Tenggara Barat", Jurnal Administrasi Publik, vol. 2, no. 3, 2014.

Silviany, Mona, "Implementasi Kebijakan Kesejahteraan Sosial Lanjut Usia di Kecamatan Palu Barat Kota Palu", E-Jurnal Katalogis, vol. 3, no. 5, 2015.

Simbolon, Pomarida \& Nagoklan Simbolon, "Association between Social-Cultural and the Utilization of Elderly Integrated Health Services (Posyandu Lansia) in Hamparan Perak Health Center", Unnes Journal of Public Health, vol. 7, no. 1, 2018. https://doi. org/10.15294/ujph.v7i1.18201

Susilawati, Nilda dkk., "Zakat Community Development Program Through A Zakat Village Index Approach", MADANIA, vol. 23, no. 2, 2019.

Syuman, Nu'aimah, Al-Islam Baina Keynes wa Marx wa Huquq al-Insan fi al-Islam, Damaskus: Ittihad al-Kuttab al-'Arab, 2000.

Tanaya, AA Raka Riani \& I Gusti Wayan Murjana Yasa, "Kesejahteraan Lansia dan Beberapa Faktor yang Mempengaruhi di Desa Dangin Puri Kauh", Piramida, vol. 11, no. 1, 2015.

Undang-Undang Dasar Negara Republik Indonesia Tahun 1945 [The 1945 Constitution of the Republic of Indonesia]

Undang-Undang Nomor 13 Tahun 1998 tentang Kesejahteraan Lanjut Usia [Law No.13 of 1998 on Elderly Wefare]

Undang-Undang Nomor 36 tahun 2009 tentang Kesehatan [Law No.36 of 2009 on Health] 
Waskito, Jati, “Faktor-faktor Pendorong Keniatan Pekerja Lansia untuk Melanjutkan Bekerja. Benefit", Jurnal Manajemen Dan Bisnis, vol. 18, no. 2, 2014.

Widiastuti, Atik, "Pengaruh Pendidikan, Jam Kerja, dan Pengalaman Kerja Terhadap Pendapatan Tenaga Kerja Lansia", Jurnal Pendidikan Dan Ekonomi, vol. 7, no. 3, 2018.
Yusuf, Abu, Al-Kharaj, tahkik Thâha Abd Ra'uf Sa'ad \& Sa'ad Hasan Muhammad, Kairo: alMaktabah al-Azhariyah li at-Turâts, t.th.

Zuhailî, Wahbah, Al-, Al-Fiqh al-Islâmi wa Adillatuhu, Beirut: Dâr al-Fikri, cet. 12, jilid. 8, 2009. 